\title{
ROZUMIENIE DOBRA I ZŁA JAKO PRZEDMIOTÓW UCZUĆ WEDEUG ŚW. TOMASZA Z AKWINU
}

W historii filozofii dobro ujmowane jest najczęściej jako przedmiot poznania rozumowego, co czyni doświadczenie dobra swoiście ludzkim przeżyciem. Odbiór dobra na innym niż rozumowy poziomie nie wzbudził żywszego zainteresowania filozofów w europejskiej tradycji filozoficznej, zaś przekonanie, że dobro może być po prostu odczuwane za pomocą emocji, pozostawało zazwyczaj poza ramami filozoficznej refleksji. Starożytna tradycja myślowa, wywodząca się od Platona i kontynuowana przez hellenistyczne szkoły filozoficzne stoików, cyników czy sceptyków, traktowała uczucia jako przeszkodę dla rozwoju duszy i poznania intelektualnego. Platońska filozofia dała pejoratywny opis uczuć, zaś stoicy i cynicy szczęścia upatrywali właśnie w stanie uwolnienia od emocji - tak zwanej apatii.

Wraz z narodzinami chrześcijaństwa konceptualizacje i analizy uczuć stały się jednak nieodzowne: w chrześcijańskim kręgu kulturowym kluczowe okazały się właśnie stany uczuciowe, takie jak miłość, skrucha czy żal za grzechy ${ }^{1}$. Argumentować można wprawdzie, że w wymienionych stanach uczuciowych mają pewien udział rozum czy wola, lecz nie sposób pojąć

${ }^{1}$ Por. na ten temat: P. King, Emotions in Medieval Thought, [w:] The Oxford Handbook of Philosophy of Emotion, red. P. Goldie, New York 2010, s. 167-187. 
miłości, skruchy czy żalu bez jakiegokolwiek aspektu emocjonalnego. Chrześcijaństwo nadało sercu i jego poruszeniom utracony w dominujących szkołach filozofii starożytnej pozytywny charakter². Patologiczność wszelkich uczuć, tak wyraźna w szkole stoickiej, została skonfrontowana z doktryną głoszącą wewnętrzne piękno i nieodzowność pewnych uczuć:

Gdybym mówił językami ludzi i aniołów, a miłości bym nie miał, byłbym jako miedź dźwięcząca albo cymbał brzmiący. I gdybym miał dar proroctwa, znał wszystkie tajemnice i posiadał wszelką wiedzę, [...] a miłości bym nie miał, niczym nie jestem $[1 \text { Kor } 13,1-2]^{3}$.

Chrześcijaństwo wprowadziło ponadto porządek w emocjonalną sferę człowieka, regulując uczucia: dekalog zakazuje choćby zazdrości, nieczystego pożądania czy chciwości. Pojęcia nazywające emocje, skoro stały się częścią nauczania Kościoła, wymagały konceptualizacji. Dlatego też chrześcijaństwo, posługując się tymi pojęciami, utorowało drogę do filozoficznych rozważań, wśród których szczególnym osiągnięciem jest koncepcja wielkiego wychowawcy i nauczyciela kultury europejskiej - św. Tomasza z Akwinu. Chociaż jego teoria uczuć jest przystępna, nie cieszyła się, ani też nadal nie cieszy, szczególnym zainteresowaniem komentatorów. Stosunkowo nieczęsto analizowany fragment dorobku św. Tomasza dotyczący zagadnienia uczuć stanowi temat niniejszego artykułu. Na podstawie myśli średniowiecznego myśliciela naświetlony zostanie ten aspekt fenomenu dobra, jakim jest jego bycie odczuwanym - by użyć strony biernej i podmiotowej -

2 Na przykład św. Bazyli Wielki uważał "gorzkie łzy” za lekarstwo na chorobę grzechu (Homilia na stowa: „Miej się na baczności”, [w:] św. Bazyli Wielki, Wybór homilij i kazań, tłum. T. Sinko, Kraków 1947, s. 40-41); Nemezjusz z Emezy w swoim poczytnym w wiekach średnich traktacie $O$ naturze ludzkiej głosił, że jedną z dwóch prerogatyw specyficznie ludzkich jest zdolność do żałowania, która stanowi podstawę przebaczenia i jest zatem czymś pożądanym przez człowieka. Demonów oraz aniołów nie stać na żal, na podstawie którego można ubiegać się o przebaczenie (Nemezjusz z Emezy, O naturze ludzkiej, tłum. A. Kempfi, Warszawa 1982, s. 25); św. Grzegorz z Nyssy, omawiając ikoniczność człowieka, podkreślał, że Bóg jest nie tylko umysłem i słowem (które człowiek odwzorowuje mową i rozumem), ale także miłością i źródłem miłości, dlatego też chrześcijanie, aby być na obraz i podobieństwo Boga, winni siebie nawzajem miłować. Gdy tego nie czynią, deformują swą ikoniczną naturę (Grzegorz z Nyssy, O stworzeniu człowieka, tłum. M. Przyszychowska, Kraków 2006, s. 60); św. Maksym Wyznawca zreinterpretował natomiast stoicką ",apatheia”, głosząc, że prawdziwą apatią jest ogołocenie się z egoizmu i wypełnienie miłością Boga i bliźniego (por. J. Baumann, Zarys historii duchowości, Kielce 1993, s. 68-69). Motyw potrzebnej skruchy i konieczności opłakiwania swych win jest obecny w apoftegmatach Ojców Pustyni (por. Apoftegmaty Ojców Pustyni, tomy 1-4, tłum. M. Borkowska OSB, M. Kozera [et al.], Kraków 2007-2011). Wątek ten u Ojców Pustyni komentuje M. Borkowska OSB: Abba, powiedz mi stowo, Kraków 2013, s. 63-64; jej uwagi w kontekście nauk poszczególnych Ojców także w: Twarze ojców pustyni, Kraków 2001.

${ }^{3}$ Pismo Święte Nowego Testamentu, tłum. E. Dąbrowski, Warszawa 1954, s. 493. 
czy też jego emocjonalna dostępność - by odwołać się do strony przedmiotowej czy zjawiskowej. Komentarz stanowić będzie rozważenie kwestii wartości moralnej uczuć.

Klasyczne sformułowanie koncepcji uczuć odnajdujemy w passusie z Summa Theologiae - a ściślej jej części etycznej (Prima Secundae) - wyodrębnianym jako De passionibus 4 . Jest to najdojrzalsze ujęcie teorii Akwinaty, jednak istotne ustalenia dotyczące uczuć odnajdujemy także w innym fragmencie tej samej części Summy (w polskim wydaniu: Traktat o cnotach $^{5}$ ) oraz w dziełach wcześniejszych, takich jak Kwestie dyskutowane o prawdzié czy Komentarz do "Sentencji" Piotra Lombarda7. Przedstawiona w tych pismach teoria uczuć zakłada spójne i konsekwentne rozumienie terminu passio, które wymaga tutaj krótkiego komentarza.

Swoistą cechą każdego przeżycia uczuciowego jest jego bierność: uczucia są czymś, co się odczuwa, czego dusza doznaje czy - by odwołać się do kolokwialnego języka - czymś, co człowieka nachodzi ${ }^{8}$. Dlatego też łacińska nazwa passio, jednoznacznie akcentująca bierny charakter uczuć, czasami oddawana była poprzez termin „doznanie" ${ }^{\prime \prime}$, aczkolwiek tradycja translatorska podążała najczęściej za językiem potocznym, stosując termin „uczucie"10. Bierność uczuć nie wystarcza jednak do określenia ich istoty. Kolejną cechą wyróżniającą te stany jest ich aspekt fizjologiczny: wszelkie uczucia mają swe odzwierciedlenie $\mathrm{w}$ reakcjach somatycznych organizmu ${ }^{11}$. Tomaszowa teza o jedności formy substancjalnej w duszy człowieka prowadzi do

4 Św. Tomasz z Akwinu, Summa Teologiczna, t. 10: Uczucia, tłum. J. Bardan, Londyn 1967.

${ }_{5}^{5}$ Św. Tomasz z Akwinu Traktat o cnotach, tłum. W. Galewicz, Kęty 2006, w szczególności q. 59 a $1-5$.

${ }^{6}$ Św. Tomasz z Akwinu, Kwestie dyskutowane o prawdzie, t. II, tłum. A. Aduszkiewicz, L. Kuczyński, J. Ruszczyński, Kęty 1998, q. 25-26; idem, Quaestiones disputate de sensualitate. De passionibus animae - Dysputy problemowe o zmystowości. O uczuciach, tłum. A. Białek, Lublin 2008.

7 Św. Tomasz z Akwinu, Scriptum super Librum Sententiarum Magistri Petri Lombardi, http://capricorn.bc.edu/siepm/DOCUMENTS/AQUINAS/Aquinas\%20Super\%20libros\%20 Sententiarum $\% 201 \% 20 \% 281929 \% 29 \% 20$ ocr.pdf (dostęp: 5.10 .2014 ), d. 15 q. 2 d. 26 q. 1 d. 27 q. 1.

${ }^{8}$ Herbert McCabe proponuje nawet, że być może termin „reakcje” byłby najlepszym tłumaczeniem Tomaszowego passio, ponieważ stosownie oddaje bierność poszczególnych passiones (H. McCabe OP, On Aquinas, New York 2008, s. 71).

${ }^{9} \mathrm{~Np}$. w tłumaczeniu Quaestiones disputatae de veritate A. Anuszkiewicza czy Quaestiones disputatae de sensualitate A. Białka. Więcej na temat bierności uczuć por. Mieczysław A. Krąpiec, Psychologia racjonalna, Lublin 1996, s. 105.

10 Por. także uwagi tłumacza, J. Bardana, w: św. Tomasz z Akwinu, Summa Teologiczna, t. 10: Uczucia, op. cit.

11 Por. na ten temat: A. Kenny, Aquinas on Mind, Topics in Medieval Philosophy, London New York 1993, s. 134; a także: R. Pasnau, Thomas Aquinas on Human Nature. A Philosophical Study of Summa Theologiae 1a 75-89, Cambridge 2004, s. 241. 
całościowego rozumienia istoty ludzkiej jako nierozerwalnej jedności duszy i ciała. Treść tej charakterystycznej dla świętego tezy w teorii uczuć sprowadza się do konstatacji, że uczucia, będące stanami człowieka, mają zarówno swój duchowy, jak i materialny aspekt ${ }^{12}$. Naturalnie, XIII-wieczne opisy reakcji somatycznych ograniczone są poprzez ówczesny stan wiedzy biologicznej - znikomej i często mylnej. Wyniki badań współczesnych nauk biochemicznych podważają niejeden z opisów owych fizjologicznych aspektów przeżywania uczuć podawanych przez św. Tomasza ${ }^{13}$. Nie umniejsza to znaczenia kwestii przekładalności uczuć na sferę cielesną człowieka. Dla średniowiecznego scholastyka był to jeden z zasadniczych wyróżników passiones.

Materialny aspekt emocjonalności należy jednak uzupełnić o kolejny wyznacznik emocji - w przeciwnym razie lista uczuć stałaby się dostatecznie szeroka, by objąć popędy czy instynkty, odróżniane od uczuć już w starożytności. Kolejna własność emocji wprowadzi nas w tematykę dobra i zła.

Św. Tomasz głosi, że zmysłowa część duszy odpowiada za reakcje emocjonalne, nie twierdzi jednak, że uczucia wyzbyte są wszelkiego aspektu poznawczego. Akwinata konsekwentnie uznaje dobro lub zło jako takie, ewentualnie dobro lub zło postrzegane jako trudne do osiągnięcia lub przezwyciężenia, za przedmioty uczuć. Innymi słowy: w uczuciach poznajemy, czy raczej - odczuwamy, dobro i zło. Odczucie tych dwóch przedmiotów wywołuje zmianę stanu duszy i ciała w odniesieniu do przedmiotu emocji i powoduje rodzaj ruchu ${ }^{14}$. Czym jest ów ruch?

Kategorię ruchu w wyjaśnieniu stanu emocjonalnego św. Tomasz zaczerpnął od Arystotelesa, bowiem to Filozof określił bycie przyciąganym do dobra lub odstręczanym od zła jako ruch duszy. Posługując się klasyczną Arystotelejską kategorią, św. Tomasz nazywa stan osoby doświadczającej uczuć poruszeniem w dwóch kierunkach: ku dobru lub też od zła. Nie należy przez to rozumieć, że osoba decyduje się na ruch, jak mogłoby sugerować stwierdzenie głoszące, że człowiek wykonuje ruch ku dobru lub od zła; taka konstatacja równałaby się uznaniu uczuć za stan aktywny. Jak już powiedziano, odczuwanie charakteryzuje bierność wobec przedmiotu: do dobra

12 Rozważanie uczuć jako stanów dotyczących zarówno duszy, jak i ciała prowadzi do konstatacji, że aniołowie, pozbawieni ciała, nie odczuwają stanów emocjonalnych. Por. na ten temat: E. Gilson, Tomizm. Wprowadzenie do filozofii św. Tomasza z Akwinu, tłum. T. Dmochowska, M. Tazbir, Warszawa 1960, s. 376.

${ }^{13}$ Choćby twierdzenie o tym, iż człowiekowi ogarniętemu gniewem dosłownie burzy się krew w żyłach, co święty uważał za fakt.

${ }^{14}$ E. Gilson pisze wprost, że „człowiek jest istotą poruszaną przez uczucia”, tym samym akcentując jednocześnie bierność człowieka wobec stanu emocjonalnego oraz ten aspekt uczucia, jakim jest jego bycie ruchem; por. E. Gilson, op. cit, s. 376. 
jest się przyciąganym, zaś od zła jest się odpychanym. Taka jest logika samych fenomenów bonum i malum: doświadczając ich za pomocą uczuć, a więc odczuwając je, osoba doznaje poruszenia. Św. Tomasz głosi zatem, że dobro i zło jawią się nam nie tylko jako przedmioty teoretycznej refleksji, filozoficznego zastanowienia, które pozostawiają myśliciela nieporuszonym. Bonum i malum, zarówno metaforycznie, jak i dosłownie, poruszają nas będąc tym samym fenomenami mającymi wpływ na całego człowieka, jego duszę i ciało.

Związek teorii uczuć z koncepcją ruchu jest argumentem, który św. Tomasz wykorzystuje np. wtedy, gdy rozważa pytanie, czy passiones mają bardziej poznawczy czy pożądawczy charakter (Summa theologiae I II-ae, q. 22, a. 2). Dziedzictwem arystotelizmu w myśli Akwinaty jest wyróżnienie trzech zasad duszy: wegetatywnej, charakterystycznej dla świata roślinnego; zmysłowej, przysługującej zwierzętom; oraz intelektualnej, kształtującej byt człowieka. Pytanie o poznawczy aspekt uczuć nie jest jednak pytaniem o swoiście ludzki ich charakter. Dusza zwierzęca posiada, niczym ludzka, zarówno część pożądawczą, jak i poznawczą - tylko dusza roślinna pozbawiona jest możliwości poznania. W duszy rozumnej występuje oczywiście unikatowy rodzaj poznania, jakim jest poznanie intelektualne, oraz swoista dla człowieka władza pożądawcza - jest nią wola. Zasada duszy rozumnej obejmuje dwie niższe zasady: wegetatywną i zmysłową, $w$ przeciwnym razie byt ludzki byłby czysto intelektualną egzystencją wyposażoną $\mathrm{w}$ wolę, a niezdolną do postrzegania, wzrostu czy odżywiania. Fakt, że passiones występują u człowieka, nie wyklucza zatem możliwości, że uczuciowość wynika ze zmysłowej zasady duszy i jest wspólna ludziom oraz zwierzętom. Pytanie brzmi zatem: czy uczucia są bardziej poznawcze czy pożądawcze oraz czy są takimi na sposób wspólny ludziom i zwierzętom, czy może na sposób wyjątkowo ludzki?

Wspomniane pytania św. Tomasz rozpatruje $\mathrm{w}$ trzech pierwszych artykułach kwestii 22 z Prima Secundae, otwierającej teorię uczuć w Summie Teologii. W pierwszym z nich Akwinata odwołuje się do koncepcji ruchu:

Jak wiadomo $\mathrm{z}$ poprzedniego artykułu, uczucie wyraża pewne przyciąganie ku czynnikowi oddziałującemu. Otóż przyciąganiu ulega raczej pożądanie niż poznanie, gdyż właśnie przez pożądanie dusza zwraca się ku rzeczom tak jak są same w sobie. Stąd Filozof stwierdza, że dobro i zło, będąc przedmiotem pożądania, zachodzą w samych rzeczach. Władza poznawcza zaś nie ulega przyciąganiu ku rzeczom tak jak one są same w sobie, lecz ujmuje je podług swego pojęcia, względnie wytwarza je na swój sposób. [...] Widać więc z tego, że istotną cechę uczuć odnajdujemy w dziale pożądawczym raczej niż poznawczym ${ }^{15}$.

15 Św. Tomasz z Akwinu, Summa Teologiczna, op. cit., s. 18. 
Konkluzja rozważania jest zatem częściowo osiągnięta, pozostaje rozstrzygnąć jedynie, czy jest to swoiście ludzkie pożądanie - voluntas, czy może pożądanie wynikłe ze zmysłowej zasady duszy. Rozumowanie dotyczące tego pytania odwołuje się do wspomnianego już somatycznego aspektu emocji. Wola, umysłowa władza pożądawcza, nie powoduje cielesnej przemiany w podmiocie jej doświadczającym. Ergo - uczucia przynależą do zmysłowej zasady duszy $w$ jej aspekcie pożądawczym. Zmysłowa część duszy ma swój element poznawczy - percepcję, oraz pożądawczy - właśnie passiones, zaś dusza rozumna dysponuje poznającym intelektem i pożądawczą wolą (appetitus intellectivus). Władzą odpowiedzialną za powstawanie uczuć jest zmysłowa władza pożądawcza - appetitus sensitivus. Określiwszy władzę duszy odpowiedzialną za stan emocjonalny, możemy przejść do charakterystyki przedmiotów passiones: bonum i malum.

Św. Tomasz rozróżnia dwa podstawowe sposoby przejawiania się dobra i zła w uczuciach. Odpowiadają im dwie odmiany władzy duszy odpowiedzialnej za występowanie emocji. Pierwszą z nich jest appetitus concupiscibilis, oddawany w języku polskim jako „popędliwa władza pożądawcza” lub "popęd zasadniczy", drugą zaś - appetitus irascibilis, tłumaczony za pomocą terminu "gniewliwej władzy pożądawczej" czy też "popędu zdobywczego" lub „popędu do walki”16. Zasadnicza różnica pomiędzy tymi dwoma typami tkwi $\mathrm{w}$ ich przedmiocie: passiones concupiscibilis nakierowane są na zmysłowo uchwytne (sensibile) dobro lub zło jako takie, zaś passiones irascibilis za swój przedmiot mają dobro trudne do osiągnięcia lub zło trudne do uniknięcia. Akwinata dzieli zatem uczucia na dwa podstawowe typy, wyróżniając je przy pomocy trzech argumentów, które można nazwać: argumentem ze współdziałania, argumentem z poddaństwa i argumentem z mistrzostwa ${ }^{17}$. W obrębie dwóch podstawowych gatunków uczuć święty wyróżnia jedenaście konkretnych emocji, opisując w każdym przypadku, czym jest przejawiające się w emocjonalnym odbiorze bonum lub malum.

Uczuć popędu zasadniczego (concupiscibilis) jest sześć i występują w trzech parach przeciwieństw. Są nimi uczucia miłości18 i nienawiści, po-

${ }^{16} \mathrm{~W}$ kwestii wyższości jednej odmiany nad drugą por. E. Gilson, op. cit, s. 337-338. Konkluzja jego rozumowania głosi wyższość władzy gniewliwej nad popędliwą.

17 św. Tomasz z Akwinu, Summa Teologiczna, op. cit., q. 23, s. 21-30. Komentarz do powyższych argumentów w: P. King, Aquinas on the emotions, [w:] The Oxford Handbook to Aquinas, red. B. Davis, New York 2012.

${ }^{18} \mathrm{~W}$ języku polskim termin amor, nazywający uczucie, oddawany jest za pomocą wyrażenia „miłość”, podobnie jak cnota miłości - caritas. Powoduje to dwuznaczność niezamierzoną przez świętego. W artykule terminem „miłość” określam uczucie, nie zaś cnotę. 
żądania i odrazy, radości i smutku, czyli kolejno: amor i odium, desiderium i fuga, gaudium i tristitia. Uporządkowane są w pary według swego stosunku do ruchu, przy czym przedmiotem pierwszego członu każdej pary jest dobro, zaś drugiego - zło. Para pierwsza, amor i odium, to proste tendencje nakierowane na przeciwne przedmioty, para druga podąża $\mathrm{w}$ ruchu ku dobru lub od zła, zaś para ostatnia znajduje spoczynek w swoich przedmiotach, i dlatego też radość i smutek nazywane są przez św. Tomasza uczuciami spoczynku. Jak zatem fenomen dobra jawi się w uczuciu miłości, pożądania i radości? Bonum jest tym, co wywołuje w podmiocie ogarniętym miłością prostą skłonność ku niemu; w pożądaniu bonum wywołuje poruszenie ku dobru, zaś w radości bonum jest tym, w czym cieszący się nim podmiot tkwi, odnajdując kres swego ruchu i spoczywając w upragnionym przedmiocie.

Pięć "gniewliwych" uczuć: nadziei i rozpaczy, zaufania i strachu oraz gniewu w sensie ścisłym, który nie ma swego przeciwieństwa, to szczegółowe postaci drugiego rodzaju pożądania zmysłowego, czyli popędu zdobywczego (irascibilis). Spes ${ }^{19}$ i desperatio, audacia i timor oraz ira to uczucia, w których dobru i złu towarzyszy trudność. Nadzieja skierowana jest na dobro, postrzegając je jako trudne, lecz możliwe do osiągnięcia; rozpacz, także mająca za swój przedmiot dobro, ujmuje je jako nieosiągalne; zaufanie to uczucie, w którym zło jawi się jako przezwyciężalne, zaś strach ujmuje zło jako realne, niemal nieuniknione zagrożenie; wreszcie gniew - emocja gniewliwa par exellence - to uczucie spoczynku w złu odczuwanym jako trudne, jeśli nie niemożliwe do pokonania.

Każde uczucie dotyczy zatem bonum i malum, co rodzi nieuchronne pytanie o moralny charakter stanu emocjonalnego. Skoro passiones mają za swój przedmiot dobro lub zło, trudno zakładać ich moralną neutralność. Ponadto, wydaje się, że w chrześcijańskiej wizji człowieka istnieją pewne nastawienia emocjonalne, takie jak miłość, wstydliwość, pogarda lub zawiść, które same z siebie zasługują na pochwałę lub naganę. Zapytać należy zatem, czy zdaniem św. Tomasza uczucia posiadają aprioryczną - pozytywną lub negatywną - wartość.

Uczucia to bierne poruszenia, które aktualizują się pod wpływem zmysłowych władz duszy rozumnej. Stan emocjonalny to stan całej osoby, a w człowieku dusza zmysłowa występuje jako element duszy racjonalnej. Emocjonalnemu poruszeniu może zatem towarzyszyć aktywność wyższych władz intelektualnych. Po pierwsze, władze intelektualne mogą wpływać na

\footnotetext{
${ }^{19}$ Spes oznacza tu uczucie, a nie teologalną cnotę nadziei.
} 
przeżywanie uczuć, jeśli wyobraźnia podsunie obrazy rozbudzające lub osłabiające daną emocję; po wtóre, jeśli rozum odwoła się do ogólnych prawd, których rozważanie osłabia lub wzmacnia dany stan ${ }^{20}$.

Także wola, intelektualna władza pożądawcza, może kontrolować uczucia. Jej decyzja może wywołać pewne emocje, jak wówczas, gdy w konsekwencji postanowienia woli - na przykład o podjęciu posługi wobec obłożnie chorych - doznać można odrazy. Ponadto, wola kontroluje przyzwolenie na wystąpienie emocji i może stawiać opór konkretnemu uczuciu. Wreszcie, władza ta wpływa na motyw działania: w obliczu nienawiści, choć uczucia dyktują inne rozwiązanie, motyw szacunku dla przykazań bożych prowadzi do ograniczenia gniewu ${ }^{21}$. Na koniec zaznaczyć należy, że to wola władna jest ukształtować trwałą postawę ku dobru, czyli dyspozycję etyczną zwaną cnotą (virtus) 22 .

Samo występowanie uczucia nie wiąże się z pozytywną lub negatywną wartością moralną - ta jest uzależniona od działania władz swoiście ludzkich: intelektu i woli. Byłoby niestosownym oczekiwać pochwały lub nagany za pojawienie się biernego stanu emocjonalnego - choćby najwyższej próby - nie jest on bowiem owocem naszych wyborów i działań23. Moralna ocena towarzyszy emocjonalnym stanom jedynie w sferze wolnego wyboru człowieka - gdy są one podporządkowane rozumowi lub woli. Nie znaczy to, że uczucia same w sobie są bezwartościowe, odnoszą się przecież do fenomenów dobra i zła w wyjątkowy sposób, którego nie mogą zastąpić poznanie rozumowe i akty woli. Sprawia to, że mają unikatową wartość w strukturze osobowej człowieka.

${ }^{20}$ Ciekawe przykłady omawia P. King w: Aquinas on the Emotions, op. cit.

${ }^{21}$ Por. R. Pasnau, op. cit., s. 241-251.

22 J.P. Torrell OP napisał, że „Tomasz jako pierwszy miał odważyć się [...] umieścić rozum w sercu wiary" (J.P. Torrell OP, Koncepcja wiedzy teologicznej wedtug św. Tomasza i pierwszych tomistów, [w:] Święty Tomasz teolog. Wybór studiów, red. M. Paluch, oprac. M. Romanek, tłum. A. Kuryś, P. Lichacz, Warszawa - Kęty 2005, s. 57-58). Parafraza tej znanej uwagi - poczynionej w kontekście rozważań nad osiągnięciami Tomasza jako myśliciela, który z teologii uczynił pełnoprawną naukę - jest na miejscu jako komentarz do Tomaszowej koncepcji uczuć. Tomasz bowiem, głosząc neutralność aksjologiczną uczuć samych w sobie, proponował udoskonalać je, właśnie umieszczając rozum (ewentualnie wolę) w sercu, rozumianym jako władza uczuciowa.

${ }^{23}$ Por. H. McCabe, op. cit., s. 71-79. Autor ten głosi, że uczucie gniewu jest dobre, ponieważ przyczynia się do rozwijania cnoty fortitudo, odwagi (s. 79), a ponadto, że wszystkie uczucia - jako dary boże - są dobrami. Autor nie omawia jednak szczegółowo zagadnienia wpływu pozostałych władz na uczucia ani kwestii wartości stanów afektywnych człowieka samych w sobie. Uwagę jego - oryginalną na tle pozostałych komentarzy, głoszących przeważnie neutralność aksjologiczną uczuć - odczytać można jako skrót myślowy. 
Saint Thomas Aquinas' Understanding of Good and Evil as Objects of Emotions

\section{Summary}

The aim of this article is to investigate the taxonomy of emotions formulated by Saint Thomas Aquinas. Thomas' vision of a human being as a unity of soul and body results in a conclusion that emotions are states of persons, yet it is possible to name a particular power of a soul responsible for the appearance of emotions - it is a sensitive appetite. Referring back to Aristotle's theory of motion, St. Thomas calls emotions passive movements of a sensitive appetite into two directions: towards good or away from evil. In this article bonum and malum are considered as objects of emotions what poses a question about the positive or negative value of purely emotional states. 